\title{
Educational Discourses in Social Work
}

\author{
Jitka Navrátilová ${ }^{1}$ \\ Pavel Navrátil ${ }^{2}$
}

\section{Contacts to authors}

1,2 Masaryk University, Faculty of Social Studies, Joštova 10, 60200 Brno jitkanav@fss.muni.cz navratil@fss.muni.cz

\section{Kontakty na autory}

1,2 Masarykova univerzita, Fakulta sociálních studií, Joštova 10, 60200 Brno jitkanav@fss.muni.cz navratil@fss.muni.cz

\begin{abstract}
An expert discussion about the nature of identity in social work has been led in the Czech Republic for more than a quarter century. This debate did not bring a definite shift in the understanding of what social work is, nor did it bring a shared stance on what its domain should be (Chytil, 2007; Navrátil \& Navrátilová, 2008; Matulayová \& Musil, 2013; Punová \& Navrátilová, 2014). However, if there is any consensus on the identity of social work, it refers to the fact that social work is a socially constructed field (Navrátil, 1998, 2013a) and therefore also multiparadigmatic or discursively open. If it is difficult or impossible to capture sectoral identity with a clear and final definition, sectoral identity can be seen in a pluralistic way through discourses. This paper is built on the premise that one of the most important factors influencing a sectoral understanding of sectoral identity is university education, which is one of the key social institutions that influence or even shape social discursive space (Etzkowitz \& Dzisah, 2012). In the paper we present the most influential contemporary discourses, which are applied in the education of social workers, and answer the question: What assumptions about the performance of social work and more generally the concept of sectoral identity are implied by the selected discourses of education in social work? Particular among these discourses is a socio-pedagogical perspective we compare these other discourses with and show what values are crucial for each of the different discourses and how they can enrich social work as a discipline. We proceed from the extensive overview of Czech, Slovak and English-language scientific literature, published in regard to the problem o educating social workers in the past twenty years.
\end{abstract}

Keywords: education, identity, social work, evidence-based discourse, reflexive discourse, competence discourse, socioeducational discourse

\section{Vzdělávací diskurzy v sociální práci}

Abstrakt: $\vee$ České republice se již více než čtvrt století vede
odborná diskuse o podstatě identity sociální práce. Tato debata
však nepřinesla jednoznačný posun v poznání, čím sociální práce je,
a ani nepřinesla sdílený postoj o tom, co by mělo být její doménou
(Chytil, 2007; Navrátil \& Navrátilová, 2008; Matulayová \& Musil,
2013; Punová \& Navrátilová, 2014). Pokud však v něčem shoda
ohledně identity sociální práce panuje, týká se toho, že sociální
práce je obor sociálně konstruovaný (Navrátil, 1998, 2013a) a tedy
rovněž multiparadigmatický, či diskurzivně otevřený. Je-li tedy 
Copyright (C) 2016 by authors and publisherTBU in Zlín.

This work is licensed under the Creative Commons Attribution International License (CC BY).

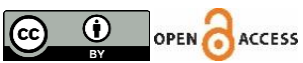

obtižné až nemožné postihnout oborovou identitu jednoznačnou a konečnou definicí, Ize na oborovou identitu nahližet pluralitně prostřednictvím diskurzů. Tato stat' pak staví na předpokladu, že jedním z nejzásadnějších faktorů ovlivňujícím chápání oborové identity je univerzitní vzdělávání, které je jednou z klíčových společenských institucí, které diskurzivní prostor sociální ovlivňují, či dokonce utváŕejí (Etzkowitz \& Dzisah, 2012). Ve stati představujeme nejvlivnější soudobé diskurzy, které se uplatňují ve vzdělávání sociálních pracovníků, a odpovídáme na otázku: Jaké předpoklady o výkonu sociální práce a obecněji o pojetí oborové identity implikují vybrané diskurzy vzdělávání v sociální práci? Specifické místo mezi těmito diskurzy zaujímá sociálněpedagogická perspektiva, s níž tyto ostatní diskurzy komparujeme a ukazujeme, jaké hodnoty jsou pro každý z jednotlivých diskurzů stěžejní a čím mohou obohatit sociální práci jako obor. Vycházíme přitom z extenzivního přehledu české, slovenské a anglicky psané odborné literatury, která k problému vzdělávání sociálních pracovníků byla publikována v uplynulých dvaceti letech.

Klíčová slova: vzdělávání, identita, sociální práce, evidence-based diskurz, reflexivní diskurz, kompetenční diskurz, sociálněpedagogický diskurz

\section{Introduction}

Social work is a field in which it is impossible to define the aim, as well as the content or performance of social workers in an exhaustive and for all contexts valid manner (McDonald, 2006). The diversity of the perception of social work affects the diversity of views on the education of social workers, and vice versa, education has a significant impact on the concept of social work. With regard to the objective of this study, it can be said that a number of approaches to learning has emerged throughout the history of social work (Lishman, 2011). One of the crucial points, in which they differ from one another, is the difference in what values social workers deem crucial when preparing for their future occupations. Some directions emphasize the need to provide students with sufficient theoretical knowledge, while other ones prefer the training of practical skills, and others emphasize the topic of self-development, critical thinking and the ability of active participation. We believe that accentuating a particular educational concept points the way not only for how the social worker will be prepared for their future profession, but also what will constitute the actual performance of social work. We proceed from the assumption that the method social workers' training affects the form of social work. Although in general terms each approach seeks to "help clients manage interaction with their social environment," they are based on different assumptions and emphasize different elements of education.

Although we can record a series of partial approaches through which social workers can be educated, for the purposes of this study we present the four main discourses that sufficiently clearly illustrate the scale of differences in the concept of preparing social workers for their future careers, both at home and abroad. They are (1) the socio-pedagogical discourse, (2) evidence-based discourse, (3) competency-based discourse, and (4) reflexive discourse. Each of them represents an important direction in social work, each emphasizing different aspects of the training of social workers. The task of this paper is to compare the differentiation of these discourses, present their different premise and their consequences for the education and experience of social workers. The presentation of the philosophical foundations which it is based on, makes it easier to understand the accents of different 
approaches in a broader context. We analyze the findings on the individual discursive approaches in order to understand their basic starting points and the direction of their original ideas. It is not so much about identifying the approach that should be perhaps the most correct, but rather about recognizing how different approaches in the education of social workers are manifested and what they are directed towards.

In the following section we will introduce the different discourses regarding the training of social workers. The structure of the analysis of discourse in education proceeds in the following structure. First we always attend to general assumptions of the relevant discourse, then we proceed to evaluate its approach to education and then analyze the identity that will be anchored in the given discursive approach.

\section{Social work and social pedagogy together, but each of them different}

In our study, we had at least two basic options on how to approach the interaction of social work and social pedagogy. First, it is possible to engage in social work and social pedagogy as two selfestablishing departments, which of course can govern common interests, theory and practice. The second option is to deal with social pedagogy as one of the discourses that found its place also in the context of social work. Given that the aim of this paper is to compare selected key discourses in social work, we choose the second perspective as dominant. The belief that this approach can be productive is also supported by the fact that it is possible to encounter the application of sociopedagogical perspectives in practical social work. For example, in Germany the socio-pedagogical aspect was significantly identified with social work, but it is also possible to encounter this view of social work in some Czech educators. Nevertheless, we consider it necessary to introduce at least briefly, how the relationship between these two disciplines crystallized.

If we look at the emergence of modern forms of both fields, then we can find some parallels in the causes of their institutionalization. Revolutionary social changes at the break of the 19th and 20th centuries associated with industrialization, urbanization and modernization, whose consequences influenced the life of all society, opened the way to the emergence of social work. Some authors (Ševčíková \& Navrátil, 2010; Navrátilová, 2015) put the emergence of the field in the context of social risks that provoked these social changes, and thanks to which a large number of individuals and entire families plunged into fatal poverty. Omnipresent poverty and the fight against it found a response in the form of various types of assistance, which have tried to eliminate the consequences of dramatic social change. Hugman (2009) points out that it is possible to trace two basic approaches to social work. The first one, which was represented by the "settlement movement" supports a structural view of social work, under which the activity of social workers should be focused on providing tools and resources to certain groups of people to change social structures and conditions that puts them at a disadvantage (Barker, 1995). Social workers are thus understood as active players who should make their clients capable of changing social conditions. This approach represents the beginnings of macro-level social work practice and focuses on the structural understanding of social issues. In this context, social workers seek to mobilize clients to make structural changes.

In the second perspective, like the first, it was about helping individuals adapt to the conditions of the social environment. Musil (2004) points out that the work of The Charity Organization staff, who were the bearers and pioneers of this trend, was however directed to assisting individuals in adapting to the conditions of the social environment through the effect on individuals and families. Hugman $(2009$, p. 1139) associates the creation of this organization with the increase of professional sensitivity at the end of the 19th century to charitable assistance for those individuals and families who experienced the problems of poverty, family breakdown, poor housing, etc. Through direct work with clients focusing on individual assistance to clients in their difficult situation, they created their own work method. It was based on the use of the relationship between those who need help, and their individual case workers. This relationship became a foundation to help the needy. Thanks to it, 
clients tried to better cope with their problems, as well as to better achieve the resources available through charitable funds and use them. One of the basic methods of social work - namely the case of social work, was formed as inspiration for the activities of these charity workers. This concept of work, which focuses on the individual functioning and issues of social order, represents the beginning of micro-level approaches in social work.

According to Human (2009), what linked these two streams was the attempt to respond to the increase in social problems arising from the processes of industrialization, urbanization and modernization, which created a massive social movement of the industrial revolution across northern Europe and North America (see Keller, 2007; Chytil, 2007). On the contrary, what divided these two approaches was the understanding of the causes of client problems and the solutions that should be applied (Hugman, 2009).

The diversity of approaches and traditions can also be seen in social pedagogy. Many authors point to the great variability, but also the diversification of social pedagogy in Europe (e.g. Lyons \& Huegler, 2012; Kornbeck \& Jensen et al., 2009; Ezechiel, 2015; Hämäläinen, 2015). As with social work, the roots of social pedagogy are clasped with large social changes, which the processes of industrialization and urbanization were characteristic for. Lyons and Huegler (2012) point out that the origins of social pedagogy are primarily associated with the two paradigms. One of them saw social pedagogy as a tool for social transformation through education communities, which was aimed at all ages. The second, which appeared in 1920 in connection with the provision of professional and academic field identity, established a closer understanding of social pedagogy as the education of children and youth living outside the school and family context. Both of these views then had a profound influence on the development of the profession itself and the field's development in individual countries. Critics of these streams have pointed to idealism and susceptibility to exploitative practices on one side, and little sensitivity to socio-political contexts on the other (Böhnisch, 1999).

The beginnings of the establishment of these industries shows that, although each of them sought to address the consequences of major social events in the daily life of individuals and communities, their accents were different. In general we can say that social pedagogical perspective saw the solution of social problems through the training of selected groups of individuals and communities as well as their growth and socialization, while the perspective of social work sought to empower and support individuals and communities in order to improve their social functioning.

It is evident that both fields are characterized by the intrinsic variability and ambiguity of objectives and identities. This diversity and ambiguity of what is the domain of social work and social education creates a space in which these disciplines can get closer together or even overlap. Another reason for these overlaps may be the fact that both disciplines work with the same target groups, use the same theoretical and conceptual resources and, ultimately, professionals from both sides strive for the same thing: they want to improve the functioning of individuals, groups and communities though they approach it from different perspectives. According to Böhnisch (1999), a significant approximation of social pedagogy and social work occurred in the 60s and 70s through an emphasis on emancipation and lifelong socialization. A shift toward education and sensitivity to socio-political aspects became typical for both professions. Important concepts that both professions worked with became those that focused on human development, personality and coping with everyday life situations in interaction with structural, social and individual factors. 


\section{Social work in the socially pedagogical discourse}

\subsection{Basis}

Hämäläinen (2015) explains that social pedagogy is associated with diverse ontological, epistemological and axiological bases. In our study, we cannot deal with social education in all its forms, but we choose what we believe very strongly influenced one of the discourses of social work. It is the area of critical theory, which moreover, according to Hämäläinen, applies in the present in social pedagogy (2015). According to Giroux (1997) and Marsh (2011) in this concept of social pedagogy it is significant that social pedagogues are understood as part of the wider world, social community, and contribute with their active influence to a critical change and empowering of the disadvantaged. The concept of social pedagogy, critical consciousness is a fundamental defining feature of social pedagogy.

One of the classic authors who followed the requirement of cultivating critical consciousness and its application when making changes, is Paolo Freire (1972). His key premise included the challenging of technical-rational education as a neutral model, arguing that many of its forms do not reject sexism, racism, exploitation and actually conserve unjust social conditions. Therefore he developed programs that should stimulate the growth of (critical) consciousness, and which may be the basis for a creative and liberating action. Freire's work aimed the focus of teachers on topics such as power, oppression, dialogue, empowerment and awakening consciousness. These ideas have become part of not only teaching practice, but influenced the development of social work and its theory. Radical, and later anti-discrimination and anti-oppressive directions, adopted the thesis on the need to promote critical awareness as their central starting point.

These procedures started to be applied in social work in the 80s and 90s, and the increase of these social work models was related to the need of some Western countries to face the explosive social problems associated with "guest workers", refugees, migrants from the east of Germany, the UK and other developed Western countries. Specific discourse of social work whose accents were clearly linked with socially critical thinking in pedagogy began to be cultivated under the banner of "antioppressive" approaches (Navrátil, 2013b).

\subsection{Approach to education}

This type of discourse understands teachers - social workers as intellectuals who are able to understand the teaching space as a place where students can explore, discuss, analyze the language of knowledge and skills. All this should lead to the growth of critical thinking skills. The sociopedagogical perspective is based on the belief that the personal growth and development of critical thinking are essential to improving the functioning of individuals and entire groups.

One of the models of critical thinking development and the development of consciousness is represented by a model of didactic planes when preparing social workers for their future profession (Sherpner, 1999). It is a model of application of social and pedagogical perspectives in the training of social workers, which should lead to the development of critical thinking and awareness especially among students, but quite naturally it also leads to the growth and progress of teachers. The application of this perspective should lead not only to a student's progress, which is not only characterized by acquiring new knowledge and skills, but also a deeper awareness of themselves, their personal background and their impact on the performance of social work. Sherpner (1999), building on the work of Garland, Jones and Kolodney (1976, pp. 17-71) defines and characterizes these five didactic levels:

(1) Information intermediation 
This plane is not only about obtaining new information on social work, but especially the development of new knowledge. So it is mainly about confronting new information with what the student already knows, what they have experienced on the level of opinions and attitudes. This didactic level significantly shapes the initial opinions and attitudes towards the performance of social work. It expands new knowledge and receives information that may become a basis for changing opinions and attitudes towards the practice. In this context, Scherpner (1999) points out one pitfall of this plane. If the teacher merely transmits information without understanding the context, this way of teaching will have little effect on student learning and will have a rather negative influence.

(2) Reflection of professional role, its development and acquisition of new methods

In this plane, the teacher encourages the student to ask critical questions. Through them they obtain the image of the subject and its context with which they work with in practice. Their questions are focused on finding ways how to proceed, how they can deal with the particular situation in the context of their experience. The teacher who leads the student within their practical experience shows them instructions on how to approach certain situations. However, they should only be some kind of guidance. The student should be encouraged to have courage in finding their own way when recognizing discrimination and oppression. At this level the student acquire specific professional methods and techniques that are intended to improve their training and professional skills. Students deepen their knowledge through direct experience.

(3) Self-education, self-reflection and self-knowledge

The personality of the social worker is one of the tools of social work. Students are therefore encouraged to be more deeply engaged with their inner integrity, their attitudes to the subject of their work, as well as professional values. They learn to distinguish their own stereotypes, prejudices and other characteristics that reduce their ability to adequately work with clients. The issues of motivation for social work come to the fore here. Motives can be different and their timely non-differentiation may lead to subsequent errors and faulty performance in the negotiations with the client. The student is slowly confronted with themselves, which they may find very difficult and sometimes unpleasant. The teacher may assist with their own emotions and experiences. By giving the student the opportunity to look into their inner feelings and experiences, the learning process may deepen for the student (Seden, 2003).

(4) Biography and life plan

Experience from critical practice, which the student has built, naturally bring the question of what this experience means for their next direction, especially for their professional life. They ask themselves questions aimed at finding answers to where they will go in their professional lives. They already have a sufficient idea of what types of difficulties and risks must be tackled in their work, and realize how this work enriches them. They have a greater awareness of their personality, their strengths and weaknesses affecting their practical execution of social work. All this gives the student the space in which they may decide. In this context, they may be able to think about their own as well as professional identity better.

(5) Transcendence and spirituality

This didactic plane refers to the fact that social work as a profession can have a spiritual and transcendent dimension both for social workers and clients. These are particularly affected in relation to human suffering. Face to face with these painful experiences, social workers are confronted with finding a deeper meaning to their life and their work. Teachers should therefore be sensitive to this area and prepare their students for it. Cultural and spiritual sensitivity is becoming an essential prerequisite for the quality practice of social work. 
Didactic planes can serve as the structure of the process in which social work students acquire skills related to critical thinking and develop their critical consciousness. The issue here is not just about the ability to understand oneself, but also about understanding one's anchor in the broader social contexts that may influence our thinking.

\subsection{The concept of identity}

The basic concept of this discourse is the concept of "oppression". This term refers to the structural disadvantages for certain groups who are denied certain rights and options normally available to the majority of the society or its elite. The aim of this concept of social work is to face these handicaps, reduce individual and institutional discrimination based on race, gender, disability, social class and sexual orientation (Thomas \& Pierson, 1995, p. 16). This concept of social work generally deals with various forms of oppression of women, members of different races, classes and ethnic groups, religious groups and other social and cultural groups. It approaches them as a complex of relationships that must be viewed from a single, discrimination revealing and declining viewing angle.

One of the authors trying to develop an anti-discrimination approach as a comprehensive model of social work is Neil Thompson (1992). According to him, it is downright dangerous if a social worker is unaware of discrimination or oppression, which the client is exposed to. Social workers here aim to highlight in particular the oppression that arises between categories of people, e.g. oppression of men against women (gender), one culture against another (ethnocentrism), between generations (ageism), healthy people towards the disabled and so on. Social worker follows the principle that intervention of social work can either strengthen or eliminate oppression. The basic values which departmental identity stands on in this approach, is justice, equality and participation.

While the concept of "enabling" was emphasized in other concepts of social work, the purpose of antidiscrimination approaches is the "empowerment" of people. While the concept of enabling is individualistic and implies social work which helps people to acquire the skills that will help them cope with the conditions in which they live, the concept of empowerment means helping people to acquire more power (control, government) over their lives and living conditions.

The hallmark of good practice in traditional social work is a sensibility to the feelings of the client. In the case of the anti-discrimination approach, a similar emphasis is put on sensitivity towards the experience of discrimination, oppression. The social worker must be able to take into account such factors as: race, ethnicity, gender, age, disability, sexual orientation, etc., and the role of these aspects in the client's situation. Failure to do so may damage the client more than help them. Another feature of classical social work is the recognition of each person's uniqueness. Representatives of the anti-discrimination approach do not want to question this value, but seeks to deepen it even more by directing attention to the fact that uniqueness is not worth talking abstractly about, and that every person is set in a quite specific social context.

\section{Social work in evidence-based discourse}

\subsection{Basis}

The approach largely came to the attention of social workers in the last decade of the 20th century. What is typical and what distinguishes it from other approaches is the emphasis on the evidencebased method. Although in other approaches to education in social work we can follow their link with research and academic tradition, this approach is primarily based on the fact that the basis for the decision-making of social workers must be scientifically (understand empirically) verified by evidence (Sackett et al., 1996; Griffith, 1999; Sheldon, 2001; Webb, 2001). Social workers are expected to be able to provide procedures and guidance that would be measurable and offer the certainty of objectivist knowledge. In social work practice, this means that proven (verified by evaluation 
research) or empirically-based interventions are utilized. Evidence is primarily used in the phase when the social worker decides on a certain intervention in the role of an expert (solving the client's problem). To reduce the risk of bad decisions made on the basis of unsubstantiated assumptions, stereotypes or even prejudices, the decision must be supported by research findings. A major role is therefore played by scientific support, which may be relevant information in the form of different statistics, research summaries, research reports and scientific papers, etc. A primary emphasis is placed on scientific evidence, because thanks to them the decision-making process when working with a client becomes more objective, based on verified evidence-based research.

In the course of its development, evidence-based social work got under certain influences essential to its current form. From the extreme view, which completely eliminated the influence of the practical experience of social workers when dealing with the cases of clients, to an approach when social workers have a certain space in the interpretation of scientific recommendation. Theses by Rubin and Babbi (2010), who developed an integrative model of scientific practice, which in the work of social workers takes into account (1) practical experience, (2) the best research evidence and, finally, (3) the client's characteristics, are an example of the moderate understating of evidencebased discourse in social work. The authors talk about the fact that none of these elements can stand off to the side, as they can mutually support one another.

\subsection{Approach to education}

The close relationship between social work with scientific methods, which have become the basis for decision-making and the intervention of social workers, naturally has a great influence on what is expected within the education and professional training of social workers. The skills that they are to gain in the course of social training derive mainly from precise scientific methodology based on gradual steps that should lead the social worker to their mastery and success in working with clients. According to Rubin and Babbi (2010), the methodology of "evidence-based practice" consists of six basic steps: (1) the formulation of basic questions, (2) a search for evidence, (3) the critical evaluation of the results of relevant work, (4) the selection of appropriate interventions, (5) the application of intervention, (6) evaluation and feedback. The aim of vocational education is to teach students to seek proper evidence, scientifically founded conclusion. It is therefore obvious that this type of training of social workers emphasizes the development of methodical thinking, capability in the use of research sources and their critical evaluation. According to Jarolímková (2004), ability to find the best proof required the information literacy of users. Only via its development, we can be successful in practice based on evidence. Therefore both students and social workers should be supported in information literacy. This support should be provided, e.g. by training, counseling centers or through specialized seminars and conferences. Within them they learn the hierarchical categorization of evidence or information sources, according to the value attributed to the "evidence-based" methodology. Study goals are focused on the acquisition of skills for the use of scientific resources and evidence that serves as support for the decision to intervene.

\subsection{The concept of identity}

The identity of social workers in this discourse is very different from the other three. The thing in which this approach is fundamentally different from others is mainly the approach to assessing the client's life situation and deciding on intervention. In the first place it is expected from a social worker here that they can accurately operationalize the client's problem and then find the appropriate scientific evidence to support an effective intervention option when working with a client. According to Novell (1990), the point is that the social worker is able to obtain resources and support scientific data carriers for their decision-making on the intervention. In this context, the emphasis is put on information fitness of social workers. If they have this skill, they can help their clients, and moreover, their work will be efficient. 
Rose (1985) points out that in the context of evidence-based practice, a social worker becomes an ingenious processor able to choose the best solution for the given situation, and thus make the best decision. Under this approach, the social worker is thought of as someone who can apply basic logical principles to clients' problems, since it is based on the fact that the clients' behavior will probably develop in a certain direction. Although there are different directions and perspectives in social work based on evidence, it is clear that the center of gravity is in finding scientific evidence. The practical experience of social workers, although it has application in this approach, does not play such a role. The position of the theoretical framework is more influential is this approach than the experience generated by practice. Less emphasis on the reflection on their own role and own identity in the process of working with the client is also an unintended consequence of this.

\section{Social work in training discourse}

\subsection{Basis}

The competence-based discourse occupies a very significant place in the training of social workers, especially in recent years. The idea that social workers should mainly learn to respond to clients' life situation with appropriate behavioral strategies during studies has become very attractive for many. In the Czech Republic, competence-based discourse penetrated most curricula in social work in the last twenty years. The survey carried out among social work educators has shown that education focused on competencies was a prevailing approach in the Czech Republic, through which students are being prepared for their future profession as social workers (Navrátilová, 2010). This shift to the training discourse is, however, also visible in other European countries, as reported by, for example, Chytil (2007), Kearney (2000), Lorenz (2007); Webb (2001), and others.

Many authors point out that competency models are based on behavioral movement, which began to emerge in the 20s and penetrated the educational systems in the 50s (Ainsworth, 1977; Kuhlmann, 2009; Parker, 2006), and massively affected the education of social workers in the past five decades in particular. A competence-based method of learning first appeared in public education of youth and soon expanded to educational programs for teachers at larger universities and became dominant in the educational programs and standards of various areas (Kuhlmann, 2009). It is worth mentioning that the American psychologist and theorist of learning, David McClelland (1973), whose article from 1973 Testing for Competence rather than Intelligence, which unleashed a storm of controversy contributed very strongly to this, and de facto launched a "competence movement" in the US (Adams, 1997). The "founding father" of the competency approach questioned its previously used model for evaluating success through intelligence tests. He pointed out that the achieved competencies should become the tool for this assessment.

Behavioral foundations highlighting interest in influencing human behavior brought elements of objectivity, quantification and certainty into education. As stated by Navrátil (2001) and Matoušek (2003), it was assumed that the results of empirical research would bring new knowledge about general laws of behavior, while every human behavior under this approach is seen as the result of what one learned or did not learn. According to Navrátil (2001), classic behaviorists do not focus on specific (empirically measurable) behavior of the individual in the context of their environment. Classical behaviorists do not follow the inner motives and causes of human behavior. On the contrary, they believe that all behavior, whether it shows signs of normality or abnormality, is learned in interaction with the environment. For this reason, behaviorists focus their attention to the conditions and circumstances that affect the learning process. Findings from observations are used to make the procedures used to re-teach undesirable behavior (Kuhlmann, 2009).

Behaviorism ideas that found their use in many social sciences (sociology, anthropology, political science, social work, psychology) have gone through numerous changes since their early beginnings. The fact that the initial disinterest of behaviorists about inner feelings and motives was replaced by a 
focus on cognitive processes associated with human experience and behavior (experiences, expectations, perceptions) may be considered among the most significant. The emergence of behavioral theories that emphasize the emotional side of human behavior next to the rational side, are an example. Such an instance can be Dryden's rational-emotional-behavioral therapy (Dryden, 2008).

Fay $(2002$, p. 152) states that the most developed and most influential theories of competence in social sciences are those that are a mainstay for rational choice. In social work we can understand this statement in response to a requirement that social workers were able to solve practical problems. Reid and Epstein (1977) who developed the task-based approach in social work responded to this request in the early 70s. The structure and methodology of this approach were to bring about fundamental changes in the activity of social workers by increasing the efficiency of solving practical problems encountered by the clients of social workers. This approach, like so many others, which sought this efficiency, are characterized primarily by: being based on research findings, structured, provide clear and specific guidelines, allow the adoption of a wide range of competencies, focus on specific objectives, targeted on the fulfillment of tasks; they are time-bound and so they mobilize efforts (Tolson, Reid, \& Garvin, 2013).

Rationality of dealing thus became synonymous with efficiency in solving client problems. The authors following behaviourist ideas consider the named characteristics to be positives and benefits, especially in the education and practical experience of social workers.

\subsection{Approach to education}

The expansion of the competence-based model affects the entire education of social workers and specifically the concept of professional experience which has a significant place in the professional training of social workers. Clark (cit. according to Arkava \& Brennen, 1996) pointed out that although the competency approach is conceived in different ways in individual study programs, it is likely that in these programs we encounter the following characteristics:

- Emphasis on outcomes rather than on the learning process. Within competency models it is usually required that the student demonstrate achievement of a specific and predefined competencies. Learning methods by which this competence is achieved are not so important. The achievement of results in itself is therefore essential, the result.

- Teaching and learning are defined in terms of performance. Students must be able to demonstrate that they are successful in demonstrating the performance desired in advance.

- Performances are understood in a behavioral approach. Performance requirements are often given very clearly and lists of commands and requirements associated with the achievement of specific competence are often compiled.

- Criteria for measuring performance are given. They determine when a student is successful in their performance and when they have not achieved the desired result. These criteria are usually presented by precise criteria that indicate different levels of competence.

Shardlow and Doel (1996) note that in the context of these models it paradoxically occurs that the end of the educational process is actually the beginning. For this reason, the attributes of a competent social worker in terms of desired behavior that fulfills the role of a social worker are very precisely described. The "behavior" is most often specified through a system of skills, which a social worker should be trained in. Each skill is operationalized at the level where it is clear what can be considered evidence of achieving the competency. This kind of education is also reflected in the relationship between teacher and pupil, as well as a social worker and client. Gabura with Pružinská (1995) talk about the educational function of a relationship. A teacher is one who teaches, who is the bearer of rules and clear instructions on how to proceed in certain situations. The student is expected to critically question these instructions. 


\subsection{The concept of identity}

Although we can say that the competence-based approach is highly popular, it simultaneously causes extensive criticism by a number of authors, both foreign and domestic. For example, Lena Dominelli (1996) examines the influence of a competence-based model in social work and its impact on the practical experience of social workers. According to Dominelli, the competence-based model simplifies different elements of complex and dynamic social interactions and reduces the social nature of its individual components. Likewise, Bogo and Vayda (1987) point out that the competence-based approach is focused on the specification of individual professional skills in measurable behavior. There is only little room for reflection on the student experience. Dominelli (1996) states that an emphasis on competence-based approach in education and social work leads to technicistic and decontextualized learning, leading to the atomization of teachings, the problems of the client and social work in general. He points out that this method of competency perception does not emphasize the achievement of the best result, but even a satisfactory standard can be understood as good enough in this sense. This can of course lead to a reduction in the quality of education. Education is seen primarily in terms of rationality and therefore effectiveness. People should acquire, or rather buy such a type of education, which will be based on market needs rather than the needs based on the reality of daily life.

Dominelli (1996) points out that the competence-based approach in social work introduces fundamental changes in social work deeper than they seem at first glance. Pressure on the implementation of the competence-based approaches is not based on user needs or aspirations of social workers, but from the ephemeral and unpredictable market, whose main driving force is to gain profit. When transferring commercial thinking into education in social work, this caused a fundamental shift in the distribution of power from professionals in social work (e.g., academics and practitioners) to those who make decisions about financial resources. Competence-based discourse in education is part of the global marketization of the welfare state and its reduction (McDonald, 2006).

Chytil (2007), Lorenz (2007) and Laan (1998) point out in connection with the privatization of education of social workers that the commodification of education means a gradual loss of the ethical identity of social work. They warn that the activity of social workers has also become a commodity that has the same value as the other offered services. Help service itself has become the subject of purchase, as it happens with common consumer goods. Hugman (1998) points out that social workers have become producers of "welfare" and service users have become consumers. The fact whether this service will be offered or not does not need to be dependent on whether the need is felt by those who need help, but whether it can withstand the competing offer of other services. This situation is, however, in many cases, inconvenient and dangerous, because the driving force of the market is profit rather than helping those in need (Nussbaum, 2011)

\section{Social work in reflexive discourse}

\subsection{Basis}

In the last two decades, reflexive approach has raised a lot of expectations in many areas of professional human activity and some authors even talk about the development of massive interest in the use of reflection in diverse areas. Interest in reflective processes was opened by authors who have begun to question the usefulness of linear thinking in applied technical professions, which besides academic knowledge also need to take into consideration not only the experience of professionals but also clients (Argyris \& Schön, 1974; Schön, 1983). In social work, this motif occurs primarily in authors from the Anglophone linguistic circle (but not exclusively). Reflexive approaches have quickly become the subject of interest to a number of scientific and educational books in social 
work, because the idea that the experiences of workers and suggestions from clients must be used for adequate decision-making in social work seemed very natural in this context (D'Cruz, Gillingham, \& Melendez, 2007; Ferguson, 2003; Chow, Lam, Leung, Wong, \& Chan, 2011; Morley, 2015; Nixon \& Murr, 2006).

It seems that in social work there is growing interest in the concepts of reflection, reflexing, etc. in the context of growing awareness of uncertainty and ambiguity of the postmodern man thrown into the world of many opportunities and risks (Bauman, 1995; Giddens, 2003). Social workers are forced to respond to the status of "blurred" professional coordinates that formerly flanked the normative practice of social workers (Musil, 2004; Musil \& Šrajer, 2008; Navrátil, 2005). Social workers are turning to reflecting their personality, experience and social conventions as a tool, which is a means of feedback and which help shape a certain perspective of thinking and practical action in the "blurred" (Musil \& Šrajer, 2008) contours of profession and society.

Jane Fook (2002) also explicitly compares reflectivity and reflexivity as well as highlights the different discourses from which these concepts have emerged. While according to Fook, reflectivity is associated more with disciplines such as management and engineering, reflexivity was formulated in the discourse of social sciences as a key research skill and associated with qualitative and especially ethnographic research. According to Fook (1999), reflectivity is based on the positivist tradition, and its purpose is to generate an objective theory, which should be deductively applied in practice. Reflectivity in social work was rather connected with the social worker's effort to distance themselves from their experiences and feelings and try to attain an objective approach to practical work. Reflecting should also serve to uncover a formal contradiction between formal theory and the practical experience of the social worker. The process of reflection is used here to deny the practical wisdom of social workers, which arises inductively from daily practice. Reflexivity is conversely associated with late-modern critique of objectivism and it values the practice of social workers more (as well as the cognitive process). Fook (2002) also states that reflectivity is more related to the process of reflection on practice, while reflexivity characterizes the social worker's ability to perceive and evaluate their impact on research or practical activities. Fook also explains that reflectivity applies particularly to efforts in understanding how things work, while reflexivity lies in efforts to bring as many different perspectives and views when thinking about the client's life situation. A comparison of selected characteristics of reflective and reflexive approach is presented in the following table 1.

Table 1

Comparison of reflective and reflexive thinking

\begin{tabular}{lll}
\hline & Reflective thinking & Reflexive thinking \\
\hline $\begin{array}{l}\text { Discursive origin } \\
\text { The nature of social reality }\end{array}$ & $\begin{array}{l}\text { Management and engineering } \\
\text { Onowledge objective }\end{array}$ & $\begin{array}{l}\text { Social sciences } \\
\text { Constructed }\end{array}$ \\
Creation of objective theory & $\begin{array}{l}\text { In-depth understanding of the } \\
\text { individual }\end{array}$ \\
Purpose of reflecting/reflexion & $\begin{array}{l}\text { Technically understand and } \\
\text { improve practice }\end{array}$ & $\begin{array}{l}\text { Cultivation of personality, } \\
\text { expanding awareness of their } \\
\text { own impact on the ongoing } \\
\text { processes }\end{array}$ \\
$\begin{array}{l}\text { Approach to practical } \\
\text { experience }\end{array}$ & $\begin{array}{l}\text { Development and application of } \\
\text { a single "correct" model of how } \\
\text { things happen and how they } \\
\text { should be influenced }\end{array}$ & $\begin{array}{l}\text { Finding different perspectives, } \\
\text { interpretations and ways of } \\
\text { solving }\end{array}$ \\
\hline
\end{tabular}


It is interesting that although Fook (2002) distinguishes the meaning of reflective and reflexive, she proposes using the concepts complementary with the fact that reflexive attitude position supports reflection of practice. In her idea, reflexive attitude is, simply put, rather a predisposition toward reflexivity, while reflection is rather a process of reviewing practice. With this step, Fook (2002) combines both concepts and makes them a part of one unit in practical terms. I will discuss the options of connecting reflectivity and reflexivity later in the third section of this chapter. Since the concept of reflexivity seems more apt to social work based on the performed comparison, I will deal with it further in greater detail and in the text below I will introduce different concepts of reflexivity and focus on identifying subtypes of reflexivity to describe their main characteristics.

\subsection{The concept of education}

Extensive work of John Dewey $(1930,1933,1947)$ affected a number of later writers who have dealt with the reflexive approach. Besides Donald Schön, who opened the gates of reflective thinking not only for social work, we can mention Jack Mezirow $(1985,1991)$ and Stephen Brookfield (1987, 1995). They engaged in the learning process, in which individuals are drawn into a reflexive evaluation of their experiences and interpretations. These authors focus primarily on the transformation of knowledge and learning, in which they suggest to critically confronting the possible interpretation of particular experience. Reflexive education is clearly focused on developing the ability of future social workers to realize different perspectives, planes and interpretations of their experiences and the experiences of clients. Within reflexive learning there are many models that can be applied in the learning process. For example, Thompson and Thompson (2008) created a threedimensional model of a reflexive approach that takes into account the development of reflective thinking and summarizes knowledge about this approach. These three dimensions of reflective approach include reflection: (a) cognitive (b) affective and (c) value.

In cognitive reflexion it comes to cultivating simple thinking and even creative thinking, which is the source of the skills of professionals, able to consider problems in their complexity and yet creatively use all possible resources to be able to approach clients in a unique way. In the context of thinking reflexion, Thompson and Thompson (2008) talk about several types of thinking that social workers should develop so that their work with clients can be professional. Social workers should thus have an open mind, receptive to the needs of clients and the context in which they live, and should be able to think analytically. Thanks to the reflection of thinking, social workers should be able to use their creative thinking in favor of the client. Unlike traditional approaches that did not recognize the importance of emotions for the helping process, the reflective approach emphasizes their significance in practice and reflecting on emotions is one of the prerequisites of this approach (Biestek, 1957; Webb, 2001).

Developing a reflexive approach in practice also brought a new perspective, which is based on the fact that just as thinking is important, the feelings also have an irreplaceable role in the process of reflexion. Thompson and Thompson (2008) note that we would make a big mistake if we did not recognize what a crucial role feelings and emotions play in the assisting process. Their significance is primarily associated with the ability to share the problems of our clients, as well as the ability to adequately respond to clients' problems. The development of the reflective approach in practice also brings the realization that emotions play a key role in working with clients, and they are even a moral compass in learning and practice. Thompson and Thompson (2008) follow the fact that within reflective practice it is absolutely necessary for emotions to be integrated as one of the basic elements of reflection. 
Social work was associated with certain values, which are an indicator of social workers. They represented something considered good and desirable in a profession. Emphasizing certain values influenced the form and shape of social work. Through them anything that is deemed appropriate, useful and appropriate to follow (Clark, 2000) was emphasized. It is therefore very important to recognize on what value foundations our work as helpers stands on. Moss (2007) remarks, that "without realizing values, our work can become dangerous. Values not only create our thoughts and feelings, but also our response." In this context, the integration of values into our practice supports congruent behaviors, through which there is a consensus on how a client is thought of, what feelings we have towards them, and how we treat them (Dryden, 2008). The absence of this consensus is risky not only for the client but also for the social worker.

The above-described dimensions and elements provide us with an idea of the structure of the reflexive approach in the training of social workers. Just mere knowledge of the structure and the pursuit of its integration into the training of social workers will likely not be enough. The key is the willingness to bring openness to the educational process and ability to integrate the diversity of human experience as a source of creativity and innovative practices.

\subsection{The concept of identity}

We believe that the reflexive discourse of social work whose key principle lies in reflective thinking represents a particularly useful way of checking the prerequisites and circumstances a social worker operates with in their work with clients. Social work is conceived as an activity that should carefully consider each step. Reflexivity in this direction is perceived as a better and more meaningful way of regulating the practice than the emerging trend to make the implementation of social work bureaucratic in all its aspects. Reflection and reflective practice are also a better and more convenient practice management model for the profession of social work than the proceduralization of its procedures, or any other restriction on the professional exercise of social workers. Reflexivity is also philosophically and ethically closer to participatory approaches that understand the client as an equal partner of the social worker. The nature of reflexivity is an effort to control the interpretation of a social worker with all stakeholders (e.g., colleagues, supervisor, clients). The aim of reflexive participation is not to reveal an objective truth, but rather open space to reflect on different truths, with which and in which all the participants and especially the clients live. Parton and O'Byrne (2000) mention the willingness of the social worker to share their insights in the living situation with the client as an important characteristic of a reflexive approach, and consider this social worker's ability as relational reflexivity.

In the context of reflexive discourse, social work can be understood as the instrument that not only wants to promote reflection on the process of social work helping professionals. It also places the responsibility to help clients reflect on their life situations so as to enable them to perform multiple critical decisions about life. According to Giddens (1992), the objective of such efforts is for citizens of all classes, ethnicities, abilities, sexual orientation and gender to be able to face questions on the meaning of life, death, intimacy and personal relationships. The purpose of such social work is the empowerment of people to enable them to take responsibility for their life and its control in the very complicated living conditions of late modernity.

\section{Conclusion}

In this paper we focused on the question: What assumptions about the performance of social work and more generally the concept of sectoral identity are implied by the selected discourses of education in social work? It is necessary to say that every discourse is inherently quite specific and also presents specific concepts of social work. In the following table 2 we attempt to clearly characterize our findings: 
Table 2

Overview of discourses

\begin{tabular}{|c|c|c|c|c|}
\hline & $\begin{array}{l}\text { Evidence-based } \\
\text { discourse }\end{array}$ & $\begin{array}{l}\text { Competence- } \\
\text { based discourse }\end{array}$ & $\begin{array}{l}\text { Reflexive } \\
\text { discourse }\end{array}$ & $\begin{array}{l}\text { Socio-educational } \\
\text { discourse }\end{array}$ \\
\hline General basis & $\begin{array}{l}\text { Social work as a } \\
\text { science }\end{array}$ & $\begin{array}{l}\text { Social work as a } \\
\text { craft }\end{array}$ & $\begin{array}{l}\text { Social work as } \\
\text { reflecting } \\
\text { partnership }\end{array}$ & $\begin{array}{l}\text { Social work as } \\
\text { empowering and } \\
\text { development } \\
\text { activity }\end{array}$ \\
\hline Key value & EVIDENCE & COMPETENCE & REFLEXION & $\begin{array}{l}\text { EMPOWERING/ } \\
\text { DEVELOPMENT }\end{array}$ \\
\hline $\begin{array}{l}\text { Approach to } \\
\text { education }\end{array}$ & $\begin{array}{l}\text { The goal is to } \\
\text { educate an expert } \\
\text { who knows what } \\
\text { is best for the } \\
\text { client }\end{array}$ & $\begin{array}{l}\text { The goal is to } \\
\text { educate an expert } \\
\text { who can solve the } \\
\text { problem }\end{array}$ & $\begin{array}{l}\text { The goal is to } \\
\text { educate an expert } \\
\text { who seeks } \\
\text { understanding }\end{array}$ & $\begin{array}{l}\text { The goal is to } \\
\text { educate an expert } \\
\text { who deepens } \\
\text { their critical } \\
\text { consciousness }\end{array}$ \\
\hline $\begin{array}{l}\text { The concept of } \\
\text { identity of SW }\end{array}$ & Expert profession & $\begin{array}{l}\text { Technical } \\
\text { profession }\end{array}$ & $\begin{array}{l}\text { Participating } \\
\text { profession }\end{array}$ & $\begin{array}{l}\text { Empowering } \\
\text { profession }\end{array}$ \\
\hline
\end{tabular}

In our work, we have tried to identify the general basis, core value, access to education and the concept of sectoral identity in every discourse. Further, we briefly summarize our findings, which are presented in figure two.

The socio-educational approach in social work emphasizes the perspective of critical thinking that enables the empowering of clients and their growth. A key aspect of evidence-based discourse is the social worker's ability to find evidence that will allow them to devise the best possible intervention. Competence-based discourse then assumes that it is essential that the social worker handle the craftsmanship, thanks to which the client will provide the best support. Reflexive discourse is based on the assumption that the best service can only come from reflecting cooperation.

These discursive bases are subsequently also reflected in the image of the adequate training of social workers. Socio-educational discourse aims to educate an expert who deepens their critical consciousness, susceptible to various forms of discrimination, and drawing up strategies to overcome them and develop the client's potential. Evidence-based discourse identifies an expert who "knows" and is able to obtain valid information as an ideal social worker. Competence discourse formulates a vision of the ideal worker as a technically equipped professional who can solve the client's problems. The ideal of a reflexive discourse is an expert seeking to understand the ambiguous dimensions of the client's situation. Each of the discourses also represents a different image of the profession. Socio-educational discourse creates an image of social work as a profession, which aims to empower individuals and communities, their growth and development of potential. In the case of evidencebased discourse, social work is depicted as an expert profession. Competence-based discourse then depicts social work as a profession of tech-savvy experts who solve life problems. Reflexive discourse represents a vision of social work as a participating profession, in which the best is a solution achieved by cooperation.

The emergence of this paper was motivated by the search of the context of social work and social pedagogy. Lyons and Huegler (2012) point out that despite the approximation of social education and social work, their relationship remains controversial and changeable. This statement is supported by research analyses conducted by Hämäläinen (2003), Kornbeck and Lumsden (2009), which identified three different approaches to these relationships: (1) the position of hostile divergence, within which social work and social pedagogy are two separate disciplines; (2) the position of convergence where both disciplines are more or less the same, and (3) the position where 
social pedagogy and social work are linked either in a complementary manner or through subordination involving the management of one of the disciplines.

In terms of the said analysis of interdisciplinary collaboration relationships, our study falls into the third position in which we point to the mutual permeability of social work and social pedagogy. We have shown how one specific concept of social pedagogy influenced the educational discourse in social work.

With our paper we wanted to contribute to the reflection of interdisciplinary cooperation in the field of education of social workers. We found that the area of education opens up significant opportunities for this collaboration. The proof of this assertion is the fact that currently one of the most important educational discourses in social work was created through interaction with the ideas of social pedagogy.

\section{References}

Adams, K. (1997). Interview with the founding father of the Competency approach: David McClelland. Competency, 4(3), 18-23.

Ainsworth, D. (1977). Examining the basis for competency-based education. The Journal of Higher Education, 48(3), 321-332. doi:10.2307/1978684

Argyris, C., \& Schön, D. A. (1974). Theory in practice: Increasing professional effectiveness. San Francisco: Jossey-Bass Publishers.

Arkava, M., L., \& Brennen, E. C. (Eds.). (1996). Competency-based education for social work. New York, Council on Social Work Education.

Barker, R. L. (1995). The social work dictionary. Washington, DC: National Association of Social Workers.

Bauman, Z. (1995). Úvahy o postmoderní době. Praha: SLON.

Biestek, F. (1957). The casework relationship. Chicago: Loyola University Press.

Bogo, M., \& Vayda, E. (1987). The Practice of field instruction in social work. Toronto: University of Toronto Press.

Böhnisch, L. (1999). Sozialpadagogik der Lebensalter: Eine einführung. Weinheim and Munich: Juventa.

Brookfield, S. D. (1987). Developing critical thinkers: Challenging adults to explore ways ot thinking and acting. San Francisco: Jossey-Bass.

Brookfield, S. D. (1995). Becoming a critically reflective teacher. San Francisco: Jossey-Bass.

Clark, C. (2000). Social work ethics: Politics, principles and practice. Basingstoke: Macmillan.

D'Cruz, H., Gillingham, P., \& Melendez, S. (2007). Reflexivity, its meanings and relevance for social work: A critical review of the literature. Br J Soc Work, 37(1), 73-90. doi:10.1093/bjsw/bcl001

Dewey, J. (1930). Human nature and conduct. New York: Modern Library.

Dewey, J. (1933). How we think. New York: Heath.

Dewey, J. (1947). O pramenech vychovatelské vědy. Praha: Jaroslav Samec.

Dominelli, L. (1996). Sociology for social work. London: Macmillian Press, Ltd.

Dryden, W. (2008). Poradenství: Stručný přehled. Praha: Portál.

Etzkowitz, H., \& Dzisah, J. (2012). The age of knowledge: The dynamics of universities, knowledge and society. Leiden: Brill. 
Ezechiel, L. (2015). Social pedagogy - new perspectives. Procedia - Social and Behavioral Sciences, $180,13-18$.

Fay, B. (2002). Současná filosofie sociálních věd: Multikulturní př́stup. Praha: Slon.

Ferguson, H. (2003). Welfare, social exclusion and reflexivity: The case of child and woman protection. Journal of Social Policy, 32(2), 199-216. doi:10.1017/S0047279402006967

Fook, J. (1999). Critical reflectivity in education and practice. In B. Pease, \& J. Fook (Eds.), Transforming social work practice: Postmodern critical perspectives (pp. 195-208). Sydney: Allen \& Unwin.

Fook, J. (2002). Social work: Critical theory and practice. London: Sage.

Freire, P. (1972). Pedagogy of the oppressed. Harmondsworth: Penguins Books.

Gabura, J., \& Pružinská, J. (1995). Poradenský proces. Praha: Slon.

Garland, J. A., Jones, H. E., \& Kolodny, R. L. (1976). Explorations in group practice. Boston: Charles River Books.

Giddens, A. (1992). The transformation of intimacy: Sexuality, love and eroticism in modern societies. Cambridge: Polity.

Giddens, A. (2003). Důsledky modernity. Praha: SLON.

Giroux, H. (1997). Pedagogy and the politics of hope: Theory, culture, and schooling. Boulder: Westview Press.

Griffiths, P. (1999). The Challenge of implementing evidence based health care. British Journal of Community Nursing, 4(3), 142-147. doi:10.12968/bjcn.1999.4.3.7502

Hämäläinen, J. (2003). The concept of social pedagogy in the field of social work. Journal of Social Work, 3(1), 69-80. doi:10.1177/1468017303003001005

Hämäläinen, J. (2015). Defining social pedagogy: Historical, theoretical and practical considerations. British Journal of Social Work, 45(3), 1022-1038. doi:10.1093/bjsw/bet174

Hugman, R. (1998). Social welfare and social value. Basingstoke: Macmillan.

Hugman, R. (2009). But is it social work? Some reflections on mistaken identities. British Journal of Social Work, 39(6), 1138-1153. doi:10.1093/bjsw/bcm158

Jarolímková, A. (2004). Evidence based medicine a její vliv na činnost lékařských knihoven a informačních středisek. Knihovnická revue, 15(2), 75-81.

Chytil, O. (2007). Důsledky modernizace pro sociální práci. Sociální práce/Sociálna práca, 7(4), 64-71.

Chow, A. Y. M., Lam, D. O. B., Leung, G. S. M., Wong, D. F. K., \& Chan, B. F. P. (2011). Promoting reflexivity among social work students: The development and evaluation of a programme. Social Work Education, 30(2), 141-156. doi:10.1080/02615479.2011.540377

Kearney, J. (2000). Social work education in Britain: A history of the commodification of social work practice and education. In W. W. Kruszyńska, \& J. Krzyszkowski, J. (Eds.), Education of social workers on the eve of the European Union's enlargement (pp. 57-66). Lodž: Absolwent.

Keller, J. (2007). Teorie modernizace. Praha: Slon.

Kornbeck, J., \& Jensen, N. R. (Eds.) (2009). The diversity of social pedagogy in Europe: Studies in comparative social pedagogies and international social work and social policy. Bremen: Europäscher Hochschulverlag. 
Kornbeck, J., \& Lumsden, E. (2009). European skills and models: The relevance of the social pedagogue. In P. Higham (Ed.), Understanding post-qualifying social work (pp. 122-131). London: Sage.

Kuhlmann, E. G. (2009). Competency-based social work education: A thirty-year retrospective on the behavioral objectives movement. Social Work a Christianity, 36(1), 70-76.

Laan, Gert van der (1998). Otázky legitimace sociální práce: Pomoc není zboží. Boskovice: Albert.

Lishman, J. (2011). Social work education and training. London: Jessica Kingsley Publishers.

Lorenz, W. (2007). Teorie a metody sociální práce v Evropě - profesní profil sociálních pracovníků. Sociální práce/Sociálna práca, 1, 62-71.

Lyons, K., \& Huegler, N. (2012). European perspectives on education for social work and social pedagogy. In J. Lishman (Ed.), Social work education and training (pp. 35-54). London: Jessica Kingsley Publications.

Marsh, S. (2011). Experiencing social education. In C. White, Journeys in social educations (pp. 1-13). Rotterdam: Sense Publishers.

Matoušek, O. (2003). Slovník sociální práce. Praha: Portál.

Matulayová, T., \& Musil, L. (2013). Social work, education and postmodernity. Theory and studies in selected Czech, Slovak and Polish Issues. Liberec: Technical University of Liberec.

McClelland, D. (1973). Testing for competence rather than for intelligence. American Psychologist, 28(1), 1-14.

McDonald, C. (2006). Challenging social work: The context of practice. New York: Palgrave Macmillan.

Mezirow, J. (1985). A critical theory of self-directed learning. In S. Brookfield, Self-directed learning: From theory to practice (pp. 17-30). San Francisco: Jossey-Bass.

Mezirow, J. (1991). Transformative dimensions of adult learning. San Francisco: Jossey-Bass.

Morley, C. (2015). Critical reflexivity and social work practice. In J. D. Wright (Ed.), International Encyclopedia of the Social \& Behavioral Sciences (pp. 281-286). Amsterdam: Elsevier.

Moss, B. (2007). Values. Lyme Regis: Russell House.

Musil, L. (2004). "Ráda bych Vám pomohla, ale": Dilemata práce s klienty v organizacích. Brno: Marek Zeman.

Musil, L., \& Šrajer, J. (2008). Dimenze životní situace rodiny. In J. Šrajer, \& L. Musil (Eds.), Etické kontexty sociální práce s rodinou (pp. 9-17). České Budějovice, Brno: Albert.

Navrátil, P. (1998). Sociální práce jako sociální konstrukce. Sociologický časopis, 34(1), 37-50.

Navrátil, P. (2001). Teorie a metody sociální práce. Brno: Marek Zeman.

Navrátil, P. (2005). Role sociální práce v pozdně-moderní společnosti. In M. Smutek (Ed.), Možnosti sociální práci na počátku 21. století (pp. 37-52). Hradec Králové: Univerzita Hradec Králové.

Navrátil, P. (2013a). Sociální konstruktivismus. In O. Matoušek (Ed.), Encyklopedie sociální práce (pp. 26-31). Praha: Portál.

Navrátil, P. (2013b). Antiopresivní přistup. In O. Matoušek (Ed.), Encyklopedie sociální práce (pp. 9296). Praha: Portál.

Navrátil, P., \& Navrátilová, J. (2008). Postmodernita jako prostor pro existenciálně citlivou sociální práci. Časopis sociální práce/Sociálna práca, 8(4), 124-135. 
Navrátilová, J. (2010). Pojetí praktického vzdělávání sociálních pracovniků (Theses, Masaryk University). Retrieved from http://is.muni.cz/th/45609/fss_d/

Navrátilová, J. (2015). Vzdělávání založené na silných stránkách jako nástroj snižování nejistot a rizik. Sociální pedagogika/Social education, 3(1), 56-69. doi:10.7441/soced.2015.03.01.04

Nixon, S., \& Murr, A. (2006). Practice learning and the development of professional practice. Social Work Education, 25(8), 798-811. doi:10.1080/02615470600915852

Nussbaum, M. C. (2011). Creating capabilities: The human development approach. Cambridge; London: Belknap Press.

Novell, A. (1990). Unified theories of cognition. Cambridge, MA: Harvard University Press.

Parker, J. (2006). Developing perceptions of competence during practice learning. British Journal of social Work, 36, 1017-1036. doi:10.1093/bjsw/bch347

Parton, N., \& O’Byrne, P. (2000). Constructive social work. London: Macmillan Press.

Punová, M., \& Navrátilová, J. (Eds.). (2014). Praktické vzdělávání v sociální práci optikou konceptu resilience. Brno: Centrum praktických a evaluačních studií.

Reid, W. J., \& Epstain, L. (1977). Task-centred practice. New York: Columbia University Press.

Rose, N. (1985). The psychological complex: Psychology, politics and society 1869-1939. London: Routledge a Kegan Paul.

Rubin, A., \& Babbie, E. (2010). Essentials research methods for social work. Belmont: Brooks/Cole.

Sackett, D. L., Rosenberg, W. M. C., \& Gray, J. A. M. (Eds.). (1996). Evidence based medicine: What it is and what it isn't. British Journal of Medicine, 312, 71-72. doi:10.1136/bmj.312.7023.71

Seden, J. (2003). Counselling skills in social work practice. Buckingham: Open University Press.

Shardlow, S., \& Doel, M. (1996). Practice learning and teaching. London: Macmillan Press LTD.

Sheldon, B. (2001). Validity of evidence based practice in social work: A reply to Stephen Webb. British Journal of Social Work, 31, 801-809. doi:10.1093/bjsw/31.5.801

Sherpner, M. (2007). Didaktické roviny sociálnych učebných procesov. In P. Navrátil, Praktické vzdělávání v sociální práci (pp. 41-45). Brno: Tribun.

Schön, S. A. (1983). The reflective practitioner: How professionals think in action. London: Temple Smith.

Ševčíková, S., \& Navrátil, P. (2010). Sociální práce jako institucionalizace rizika v pozdně moderní době. Sociální studia, 7(2), 115-133.

Thomas, M., \& Pierson, J. (Eds.). (1995). Dictionary of social work. London: Collins Educational.

Thompson, N. (1992). Existentialism and social work. Aldershot: Avebury.

Thompson, S., \& Thompson, N. (2008). The critically reflective practitioner. New York: Palgrave Macmillan.

Tolson, E. R., Reid, W. J., \& Garvin, C. D. (2013). Generalist practice: A task centered approach. New York: Columbia University Press.

Webb, S. A. (2001). Some consideration on the validity of evidence-based practice in social work. British Journal of Social Work, 31, 57-79. doi:10.1093/bjsw/31.1.57 